\title{
Principal Competency Correlation, Work Motivation, and Job Satisfaction on Teacher Performance
}

\author{
Sari Nusantara Putri, Yatim Riyanto, Karwanto \\ Department of Educational Management \\ Post-Graduate, Universitas Negeri Surabaya \\ Surabaya, Indonesia \\ sariputri16070845001@mhs.unesa.ac.id
}

\begin{abstract}
This study aimed to examine the correlation of 1) principals' competence on teacher performance; 2) work motivation on teacher performance; 3) job satisfaction on teacher performance; and 4) headmaster competence, work motivation, and job satisfaction along with teacher performance. This research used a correlational quantitative method and the data were collected thorugh the principal competence questionnaire, work motivation and job satisfaction, and teacher performance observation sheet. The results of the study showed that: 1) the principals' competence has a positive and significant effect on the performance of the teachers of State Senior High Schools in Pamekasan sub-district; 2) work motivation of teacher performance on the teacher performance; and 3) job satisfaction on the teacher performance; while the highest significant effect is on 4) principals' competence, work motivation and job satisfaction to the teacher performance of State Senior High School in Pamekasan Sub-district.
\end{abstract}

Keywords-principal competency; motivation; job satisfaction; job performance

\section{INTRODUCTION}

Education is an attempt to prepare knowledgeable generation. The educational process shows activity in the form of action through active interaction which is carried out consciously in achieving the desired goals. Education is active and directed and it is an activity done consciously to produce human intelligent, skilled, independent, disciplined and have noble behavior or morals. In accordance with the law no. 20 of 2003 on the National Education System [1], in addition to the National Education Standards, to be met in the implementation of education in accordance with the Regulation no. 19 of 2005 on National Education Standards [2]. One standard which is directly related to the competence of graduates is the standard of education and education personnel. The ability of the principal in managing the school to be a reference in the success of the learning process in school is managing each component in the school. In the Regulation of the Minister of National Education Number 13 of 2007 on Principal/Madrasah Standards, a principal/madrasah should have five dimensions of minimal competence: managerial, entrepreneurial, supervision and social competence [3]. These five competency standards are integrated into the principal's leadership. The principal is a figure in guiding and providing direction to the teachers in developing competence, and ability in the learning process to produce the best quality of graduates.
In fact, there are several gaps in teacher competencies which impacted on teacher performance. Data indicating that teacher competence is less than optimal. Based on UNESCO's report on Global Education Monitoring (GEM) in 2016, Indonesia's education is in the 10th position of 14 developing countries. Besides, teacher, the important element of education, is in the 14th position from 14 developing countries [4]. Indonesian education is still far from adequate category. Also, the amount of education budget does not make the quality of education increase.

Teachers are professional educators with the main task to educate, teach, guide, direct, assess, and evaluate learners. Teachers must have a professional sense when completing their work. According to Law No. 14 of 2005 on Teachers and Lecturers, professional is "works or activities undertaken by someone and become a source of livelihood requiring expertise or skill which meets certain quality or norm standards and requires professional education" [5].

Teacher performance has an important role in achieving school goals. The performance can be seen in the process and the work. Every job always has a working procedure which aims at improving results in accordance with work procedures. Teacher performance is defined as a benchmark of teacher success in carrying out its work in accordance with responsibilities and authority based on predetermined performance standards in achieving educational goals. Teacher performance is clearly demonstrated in the learning process, and then it will produce good student achievement. Rotem and Glasman [6] describe good performance as it is seen from the results obtained in the assessment of learners' learning outcomes.

Assessing teachers' performance can be performed in the aspects of content knowledge, behavior skill, and human relations skill mastery. According to Dunkin [7], performance assessment is necessary because teachers' performance assessment is useful to discover the improvement of work performance.

Ministry of education and culture performed analysis and improvement in the implementation of education. It is also a government effort to improve teachers' professionalism. The Ministry of Education and Culture finally issued the regulation of teachers' obligations No. 18 of 2007 in following the Teacher Competency Test [8]. 
From the results of the test conducted in 2017, it showed that only 1 province achieved higher score than the passing grade of the national target for the minimum competency standards, namely 70 .

DKI Jakarta province achieved 72.22 while East Java province achieved 66.07. This means that the test result had increased when compared to the previous year. However, East Java province did not achieve higher score than the passing grade.

Pincipals are obliged to follow and comply applicable laws and regulations as well as motivate, lead, coordinate and instruct teachers, education personnel, and all school members to ensure that job satisfaction is met. From the above background, the author proposed a research entitled "Principal Competency Correlation, Work Motivation, and Job Satisfaction on Teacher Performance of State Senior High School in Pamekasan Sub-district".

\section{METHOD}

This is quantitative correlational reasearch with data obtained in the form of numbers. Then, the data were processed using statistical aid and interpreted to reveal the influence between independent variables of principal competence, work motivation, and job satisfaction on dependent variable, high school teacher performance in Pamekasan Sub-district.

\section{A. Research design}

The design of research was to know if there was the action of the relation between the object to study. The design of this research was the competence of principal $(X 1)$, work motivation $(X 2)$ and job satisfaction $(X 3)$ to teacher performance $(Y)$ as follows.

\section{B. Population and Sample}

The number of samples from 157 teacher population in Slovin formula [9] with 5\% tolerance value, then it was obtained teacher sample to use in this research of 112 teachers.

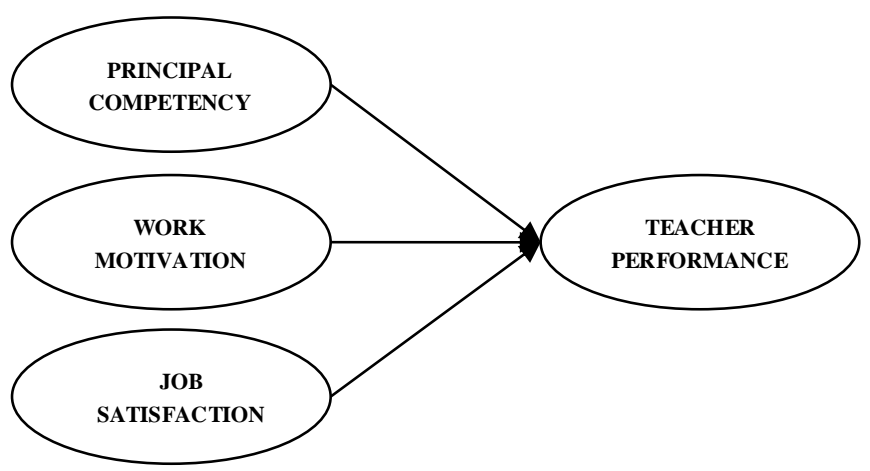

Fig. 1. Variable on the research design
TABLE I. NUMBER OF TEACHERS

\begin{tabular}{|c|l|c|}
\hline \multicolumn{1}{|c|}{ School Name } & \multicolumn{1}{|c|}{$\begin{array}{c}\text { The Name of The } \\
\text { Principal }\end{array}$} & $\begin{array}{c}\text { Total Number } \\
\text { of Teachers }\end{array}$ \\
\hline SMA N 1 Pamekasan & Dra. Hj. Faridah, M.M.Pd. & 45 \\
\hline SMA N 3 Pamekasan & Drs. H. Abdul Azis, M.Pd. & 43 \\
\hline SMA N 4 Pamekasan & H. Moh. Arifin, M.Pd. & 43 \\
\hline SMA N 5 Pamekasan & Drs. M. Hedir, M.M.Pd. & 26 \\
\hline \multicolumn{2}{|c|}{ TOTAL } & $\mathbf{1 5 7}$ \\
\hline
\end{tabular}

\section{Data Collection Techniques and Research Instruments}

In this study, the data were collected through questionnaire and observation. The questionnaire is a tool to collect data in the form of a list of written questions distributed to the respondent [10]. The questionnaires were used to measure the variables of principal's competence, work motivation, and job satisfaction. In filling the questionnaire, the respondents circle or gave a checklist $(\sqrt{ })$ on alternative answers selected in accordance with the opinions or views of respondents. The observation is a method of collecting data using to the object research. Observation can be implemented directly or indirectly [11]. In this study, the data obtained from observation were the teacher performance data in the process of learning in the classroom.

\section{Instrument Testing}

Based on the results of the validity test of principal competency variable, work motivation, job satisfaction, and teacher performance are as follows.

TABLE II. THE RESULTS OF THE VALIDITY TEST

\begin{tabular}{ccc}
\hline \multirow{2}{*}{ r table $=\mathbf{0 , 1 8 6}$} & \multicolumn{2}{c}{ Questions } \\
\cline { 2 - 3 } & Valid & Invalid \\
\hline Principal Competency & 22 & 8 \\
Work Motivation & 17 & 3 \\
Job Satisfaction & 26 & 4 \\
Teacher Performance & 29 & 8 \\
\hline
\end{tabular}

Based on the result of a reliability test of the principal competence variable, work motivation, job satisfaction, and teacher performance are as follows.

TABLE III. THE RESULTS OF RELIABILITY TEST

\begin{tabular}{ccc}
\hline \multirow{2}{*}{ Variable } & \multicolumn{2}{c}{ r table $=\mathbf{0 . 1 8 6}$} \\
\cline { 2 - 3 } & Cronbach alpha value & $\begin{array}{c}\text { Reliability } \\
\text { information }\end{array}$ \\
\hline Principal Competency & 0.435 & Reliable \\
Work Motivation & 0.625 & Reliable \\
Job Satisfaction & 0.370 & Reliable \\
Teacher Performance & 0.193 & Reliable \\
\hline
\end{tabular}

Reliability test results show that all items of the questions of the four variables studied are reliable because they have value of Cronbach Alpha $=0.186$. 


\section{E. Data analysis technique}

Data analysis techniques used in this study were simple regression analysis, f-test, t-test, Descriptive Statistical Analysis, Normality Test, Linearity Test, Heteroscedasticities Test, Autocorrelation Test, and Multicollinearity Test.

\section{RESUlTS AND DisCUSSION}

\section{A. Descriptive Statistics Analysis}

Based on the results of descriptive statistical analysis above in the show there were 112 of respondents $(N)$. These respondents consisted of teachers of senior high schools at Pamekasan sub-district. Explanation of values obtained by each variable will be explained as follows.

a In the principal competency variable the maximum value is 104 and the minimum value is 76 , the average value of 112 respondents is 92.54 with a standard deviation of 8.582 .

b In the work motivation variable the maximum value is 76 and the minimum value is 60, the average value of 112 respondents is 66.82 with a standard deviation of 3.498 .

c In the variable job satisfaction the maximum value is 105 and the minimum value is 75 , the average value of 112 respondents is 94.84 with a standard deviation of 8.277.

$\mathrm{d}$ In the teacher performance variable the maximum value is 129 and the minimum value is 88 , the average value of 112 respondents is 104.86 with a standard deviation of 9.656 .

\section{B. Multiple Linear Regression Analysis}

a The t-table value is found to be a value of t-table of 1.981 . based on the results of the regression analysis obtained the t-count value of the principal competency variable is $2.519>t-$ table and the significance value is $0.025<$ 0.05. Then it was concluded that the competence of the principal $(X 1)$ had an effect on the teacher's performance $(Y)$.

b The t-table value is found to be a value of t-table of 1.981 . based on the results of regression analysis obtained the value of a t-count variable of work motivation is $3.306>$ $t-$ table and significance value of $0.029<0.05$. Then it was concluded that work motivation $(X 2)$ had an effect on the teacher's performance $(Y)$.

c The t table value is found to be a value of t table of 1.981 . based on the results of regression analysis obtained t-count of job satisfaction variables of $2.602>t-$ table and a significance value of $0.010<0.05$. Then it was concluded that job satisfaction $(X 3)$ had an effect on the teacher's performance $(Y)$.

$\mathrm{d}$ F-count value is 10.485 and $f-$ table $=2.69$. Because the value of $F-$ count $>F$-table then it can be concluded that the independent variables $X 1, X 2$, and $X 3$ influence simultaneously on the dependent variable $Y$.

\section{Normality Test}

Normality test is known that the significance value of 0.742 is greater than 0.05 , so it can be concluded that the data tested normal distribution.

\section{Linearity Test}

a In the competence variable of the headmaster $(X 1)$, the value of significance 0.535 greater than 0.05 means that there is a linear relationship between principal competence variable $(X 1)$ and teacher performance variable $(Y)$.

$\mathrm{b}$ On the variable of work motivation $(X 2)$ is obtained significance value 0.475 greater than 0.05 which means there is a linear relationship between work motivation variable $(X 2)$ with teacher performance variable $(Y)$.

c On the job satisfaction variable $(X 3)$ obtained significance value 0.770 greater than 0.05 which means there is a linear relationship between job satisfaction variables $(X 3)$ with teacher performance variables $(Y)$.

\section{E. Heteroscedasticity Test}

Heteroscedasticity test found significance value of competence variable of principal $(X 1)$ equal to 0.744 bigger than 0.05 meaning that there is no heteroscedasticity competence of principal $(X 1)$, while significance variable of work motivation $(X 2)$ equal to 0.022 less than 0.05 meaning there is work motivation heteroscedasticity $(X 2)$ and value of job satisfaction variable significance $(X 3)$ equal to 0.814 bigger than 0.05 meaning that there are no heteroscedasticity on job satisfaction variable $(X 3)$.

Scatterplot

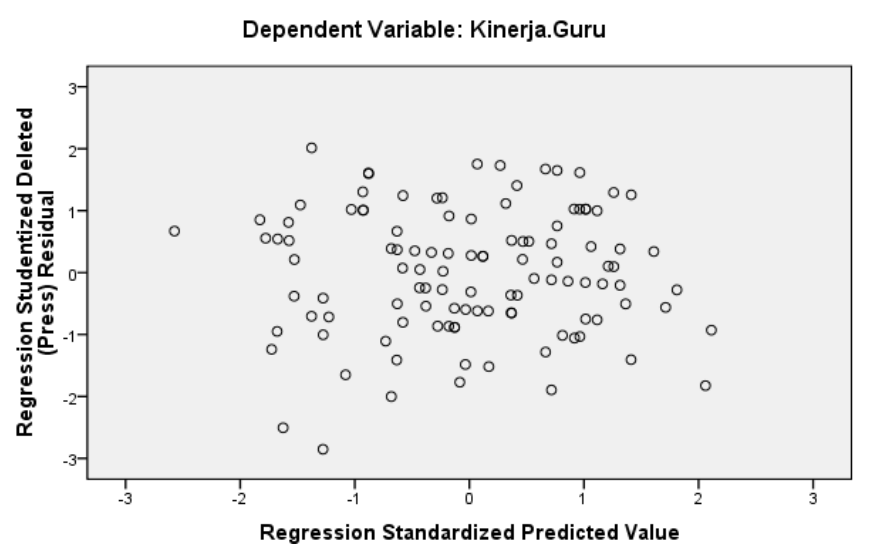

\section{F. Multicollinearity Test}

In the multicollinearity test, it is known that VIF value of principal competence variable (1.273), work motivation variable (1.270), and job satisfaction variable (1.022) because VIF value for all variables $<10$ can be concluded not multicollinearity disorder. 


\section{G. Autocorrelation Test}

Location of DW count is smaller than the DW Calculate, $1.846<2.272$ means that there is no autocorrelation area then it can be concluded that the linear regression model does not occur autocorrelation.

\section{CONCLUSION}

Principal competency correlation on teacher performance

Principal competency variable has a positive and significant effect on teacher performance by $43 \%$. The f-test shows $f$-table $<f-$ count, which is $2.69<14.766$ with a significance value of $0.000<0.05$. Furthermore, the regression model found is $Y=69.040+0.387 X 1$. It can be concluded if the competency of the principal is zero, the teacher's performance in constant learning is 69.040 while the teacher's work motivation is increased by 1 point the teacher's performance will increase 0.387 points in a constant of 69.040. With the value of the influence shown $r-x I y=$ 0.661 . The principal competency coefficient of 0.387 is obtained $t$-table $<t-$ count, which is $1.981<3.843$ with a significance value of $0.000<0.05$. The results of this study are in line with the findings of Marks and Printy's research [12] that there is a correlation between the competence of school principals and teacher performance. So, it can be concluded that the competence of principals has a correlation to teacher performance, the higher the competency possessed by the principal, the better the teacher's performance will be.

\section{Correlation of work motivation to teacher performance}

Work motivation variables have a positive and significant effect on teacher performance by $47 \%$. The f-test shows $f-$ table $<f$-count, which is $2.69<17.735$ with a significance value of $0.000<0.05$. Furthermore, the regression model found is $Y=36.131+1.028 \times 2$. This can be concluded if the work motivation is zero, then the teacher's performance in constant learning is at a value of 36.131 while if the teacher's work motivation is increased by 1 point then the teacher's performance will increase by 1.028 points in a constant of 36.131 with the value of the influence as shown $r-x I y=0.692$. The motivational coefficient of 1.028 was obtained $t$-table $<t-$ count, which is $1.981<4.211$ with a significance value of $0.000<0.05$.

The correlation of job satisfaction with teacher performance

Job satisfaction variables have a positive and significant effect on teacher performance by $45 \%$. The f-test showed $f-$ table $<f$-count, which is $2.69<2.749$ with a significance value of $0.000<0.05$. Furthermore, the regression model found is $Y=87.580+0.182 X 3$. It can be concluded if job satisfaction is zero, then the teacher's performance in constant learning at a value of 87.580 while if the teacher's work motivation is raised by 1 point then the teacher's performance will increase 0.182 points in a constant of 87.580 with the value of the effect showed $r-x 2 y=$ 0.692. Job satisfaction coefficient 0.182 obtained $t-$ table $<t$-count, which is $1.981<2.602$ with a significance value of $0.000<0.05$. This opinion is reinforced by the theory of Robbins, Judge, Millett, and Boyle [13] in their explanation mentioned that someone with a level of job satisfaction high shows a positive attitude towards the job, while someone who is not satisfied with his job shows a negative attitude towards the work done.

Principal Competency Correlation, Principal Motivation, Work Motivation and Job Satisfaction on Teacher Performance

Based on multiple regression analysis, the regression equation line $Y=1.703+0.271 X 1+0.800 X 2+0.260 X 3$ means that if the competence of the principal, work motivation, and job satisfaction is zero, then the teacher's performance in the cash learning process is 1.703 . If the principal's competency increases by 1 point then the teacher's performance increases by 0.271 from the principal competency variable, if work motivation increases by 1 point then the teacher's performance increases by 0.800 and if job satisfaction increases 1 point then the teacher's performance increases by 0.260 from the variable job satisfaction. The correlation of principal competency, work motivation and job satisfaction together on the teacher's performance is shown by the correlation coefficient $r-x 1 y x 2 y x 3 y=0.723$. The correlation obtained from the competence of the principal, work motivation and job satisfaction is significant. The correlation significantly from the competence of school principals, work motivation and job satisfaction on the performance of public high school teachers throughout Pamekasan District by $56 \%$ is an adequate category, while the remaining $44 \%$ is influenced by other factors such as the work environment, school organizational culture, teacher education qualifications, and teacher work experience. this is due to the implementation of the principal's competency function through the motivation given in meeting needs in accordance with Maslow's theory, and a sense of satisfaction with work in meeting the needs for achievement needs, the need for power and the needs of affiliates in accordance with Mc Clelland's theory that can improve teacher performance, namely in learning planning, carrying out learning, carrying out assessments and conducting follow-up evaluations [14].

\section{REFERENCES}

[1] R. I. Undang-Undang, "no. 20 tahun 2003 tentang Sistem Pendidikan Nasional," Bandung: Citra Umbara, 2003.

[2] U. No, "Tahun 2005.(2005)," Tentang Standar Nas. Pendidik., 19AD.

[3] P. M. P. N. R. Indonesia, "Nomor 13 Tahun 2007 tentang Standar Kepala Sekolah/Madrasah," Biro Huk. dan Organ. Dep. Pendidik. Nas., 2007.

[4] S. and C. O. (UNESCO) United Nations Educational, "Global education monitoring report summary 2016: education for people and planet: creating sustainable futures for all," 2016.

[5] U.-U. R. Indonesia, "No. 14 Tahun 2005," Guru dan Dosen Daft. Pustaka, 2005.

[6] A. Rotem and N. S. Glasman, "On the effectiveness of students' evaluative feedback to university instructors," Rev. Educ. Res., vol. 49, no. 3, pp. 497-511, 1979.

[7] M. J. Dunkin, “Assessing teachers' effectiveness," Issues Educ. Res., 
vol. 7, no. 1, pp. 37-51, 1997.

[8] P. No, "Tahun 2007 tentang Sertifikasi Guru dalam Jabatan." Depdiknas, 18AD.

[9] S. Ellen, "Slovin's formula sampling techniques." Fort Worth: Dryden Press, 2012.

[10] K. Kelley, B. Clark, V. Brown, and J. Sitzia, "Good practice in the conduct and reporting of survey research," Int. J. Qual. Heal. care, vol. 15, no. 3, pp. 261-266, 2003.

[11] H. R. Bernard and H. R. Bernard, Social research methods: Qualitative and quantitative approaches. Sage, 2012.

[12] H. M. Marks and S. M. Printy, "Principal leadership and schoo performance: An integration of transformational and instructional leadership," Educ. Adm. Q., vol. 39, no. 3, pp. 370-397, 2003.

[13] S. Robbins, T. A. Judge, B. Millett, and M. Boyle, Organisational behaviour. Pearson Higher Education AU, 2013.

[14] S. Dharma, "Manajemen Kinerja: Falsafah Teori dan Penerapannya," Yogyakarta: Pustaka Pelajar, 2005. 